University of Nebraska - Lincoln

DigitalCommons@University of Nebraska - Lincoln

\title{
Influence of Snow and Ice Crystal Formation and Accumulation on Mercury Deposition to the Arctic
}

Thomas A. Douglas

Fort Wainwright, Alaska

Matthew Sturm

Fort Wainwright, Alaska

William R. Simpson

University of Alaska Fairbanks

Joel D. Blum

University of Michigan

Laura Alvarez-Aviles

University of Alaska

See next page for additional authors

Follow this and additional works at: https://digitalcommons.unl.edu/usarmyresearch

Part of the Operations Research, Systems Engineering and Industrial Engineering Commons

Douglas, Thomas A.; Sturm, Matthew; Simpson, William R.; Blum, Joel D.; Alvarez-Aviles, Laura; Keeler, Gerald J.; Perovich, Donald K.; Biswas, Abir; and Johnson, Kelsey, "Influence of Snow and Ice Crystal Formation and Accumulation on Mercury Deposition to the Arctic" (2008). US Army Research. 61. https://digitalcommons.unl.edu/usarmyresearch/61

This Article is brought to you for free and open access by the U.S. Department of Defense at DigitalCommons@University of Nebraska - Lincoln. It has been accepted for inclusion in US Army Research by an authorized administrator of DigitalCommons@University of Nebraska - Lincoln. 


\section{Authors}

Thomas A. Douglas, Matthew Sturm, William R. Simpson, Joel D. Blum, Laura Alvarez-Aviles, Gerald J. Keeler, Donald K. Perovich, Abir Biswas, and Kelsey Johnson 
Influence of Snow and Ice Crystal Formation and Accumulation on Mercury Deposition to the Arctic

THOMAS A. DOUGLAS, ${ }^{*}{ }^{\dagger}$

MATTHEW STURM, ${ }^{\dagger}$

WILLIAM R. SIMPSON, ${ }^{\ddagger}$ JOEL D. B L U M,

LAURA ALVAREZ-AVILES, ${ }^{\ddagger}$

GERALD J . KEELER, $\triangle$

DONALD K. PEROVICH, ${ }^{\perp}$ ABIR BISWAS,

A N K KLSEY JOH N O N $\$$

Cold Regions Research \& Engineering Laboratory, Fort

Wainwright, Alaska, Department of Chemistry and

Geophysical Institute, University of Alaska Fairbanks,

Fairbanks, Alaska, Department of Geological Sciences and Air

Quality Laboratory, University of Michigan, and Cold Regions

Research \& Engineering Laboratory, Hanover, New Hampshire

Received February 27, 2007. Revised manuscript received November 27, 2007. Accepted December 4, 2007.

Mercury is deposited to the Polar Regions during springtime atmospheric mercury depletion events (AMDEs) but the relationship between snow and ice crystal formation and mercury deposition is not well understood. The objective of this investigation was to determine if mercury concentrations were related to the type and formation of snow and ice crystals. On the basis of almost three hundred analyses of samples collected in the Alaskan Arctic, we suggest that kinetic crystals growing from the vapor phase, including surface hoar, frost flowers, and diamond dust, yield mercury concentrations that are typically 2-10 times higher than that reported for snow deposited during AMDEs ( $\sim 80 \mathrm{ng} / \mathrm{L})$. Our results show that the crystal type and formation affect the mercury concentration in any given snow sample far more than the AMDE activity prior to snow collection. We present a conceptual model of how snow grain processes including deposition, condensation, reemission, sublimation, and turbulent diffusive uptake influence mercury concentrations in snow and ice. These processes are time dependent and operate collectively to affect the retention and fate of mercury in the cryosphere. The model highlights the importance of the formation and postdeposition crystallographic history of snow or ice crystals in determining the fate and concentration of mercury in the cryosphere.

\section{Introduction}

Mercury is predominantly present in the atmosphere as gaseous elemental mercury $\left(\mathrm{Hg}^{0}, \mathrm{GEM}\right)$. It has a residence time of roughly one year and about two-thirds of emissions

* Corresponding author fax: (907) 353-5142; e-mail: thomas.a. douglas@usace.army.mil.

${ }^{\dagger}$ Cold Regions Research \& Engineering Laboratory, Fort Wainwright, Alaska.

F University of Alaska Fairbanks.

${ }^{\S}$ Department of Geological Sciences, University of Michigan.

${ }^{\triangle}$ Air Quality Laboratory, University of Michigan.

${ }^{\perp}$ Cold Regions Research \& Engineering Laboratory, Hanover, New Hampshire. are the product of anthropogenic sources such as coal combustion and waste incineration (1). Wildfires, soil emission, and volcanic and hydrothermal inputs provide the remaining one-third (2). Mercury has received considerable attention because it is a neurotoxin in its methylated form and it biomagnifies in aquatic food webs (3) leading to elevated levels in fish and piscivorous mammals (4).

In the Arctic springtime, GEM is oxidized to reactive gaseous mercury (RGM) that can be deposited to snow and ice surfaces. A unique series of photochemical reactions between ozone and halogens during polar spring create reactive halogen species such as Br radicals (5) that oxidize GEM to RGM (6). The reactions cause GEM concentrations in the Arctic lower troposphere to decrease from the typical global background of $1.6 \mathrm{ng} / \mathrm{m}^{3}$ (7) to barely detectable values $\left(<0.1 \mathrm{ng} / \mathrm{m}^{3}\right)$ for a period of hours to days as the RGM is created and deposited (8-10). Dozens of these atmospheric mercury depletion events (AMDEs) occur between late February and the onset of snowmelt in early June. Though a direct link has never been firmly established, it is believed that sea ice $(9,11,12)$, frost flower crystals on newly formed sea ice $(13,14)$, or snow with marine aerosols $(15,16)$ are necessary for AMDEs to occur because they are the reactive halogen source.

The total mercury concentrations measured in snow collected during AMDEs had been previously reported to reach a maximum of $\sim 100 \mathrm{ng} / \mathrm{L}$ (8), but we recently found considerably higher mercury concentrations in snow and ice crystals near sea ice leads (10). Frost flowers had values ranging from 154 to $185 \mathrm{ng} / \mathrm{L}$, whereas one surface hoar sample collected near a lead had a value greater than 800 $\mathrm{ng} / \mathrm{L}$. Both sample types consist of ice crystals grown directly by water vapor deposition. This suggested that proximity to an open lead in the sea ice, which produces abundant water vapor, might result in greater deposition of mercury to snow and ice crystals. On the basis of this, we hypothesized that in addition to an AMDE, the method of water vapor deposition as a condensate was a key element in depositing mercury to the near-coastal Arctic environment. To test this hypothesis, we measured mercury concentrations in a wide variety of snow and ice crystal types, both near and distant from a lead, during AMDE and non-AMDE periods. We reasoned that the formation and depositional history of different snow or ice crystals might ultimately control mercury deposition to the Arctic coastal environment.

This work presents results from a detailed investigation of primary mercury deposition to snow and ice crystals in the Arctic. Of utmost importance for ecological quantification of mercury deposition to the Arctic is the mercury concentration in snowmelt and surface water during spring and summer. We have observed end of season mercury concentrations in the total vertical isothermal snowpack during melt of 15 to $30 \mathrm{ng} / \mathrm{L}$. In addition, the mercury concentration of surface water in a small creek draining our sampling area in 2006 ranged between 10 and $15 \mathrm{ng} / \mathrm{L}$ during the 10 day peak snowmelt runoff period.

\section{Experimental Section}

Study Design. We collected snow and ice crystals in the air, on the ground, and on sea ice near Barrow, Alaska $\left(71^{\circ} 18.5^{\prime} \mathrm{N}\right.$, $156^{\circ} 31.9^{\prime} \mathrm{W}$; Figure 1). We sampled repeatedly to determine how mercury deposition changed with time and AMDE status. Sampling was paired with atmospheric monitoring of GEM and RGM to determine when AMDEs were occurring. The NOAA Climate Monitoring and Diagnostics Laboratory (CMDL) is located in Barrow and provides atmospheric ozone 


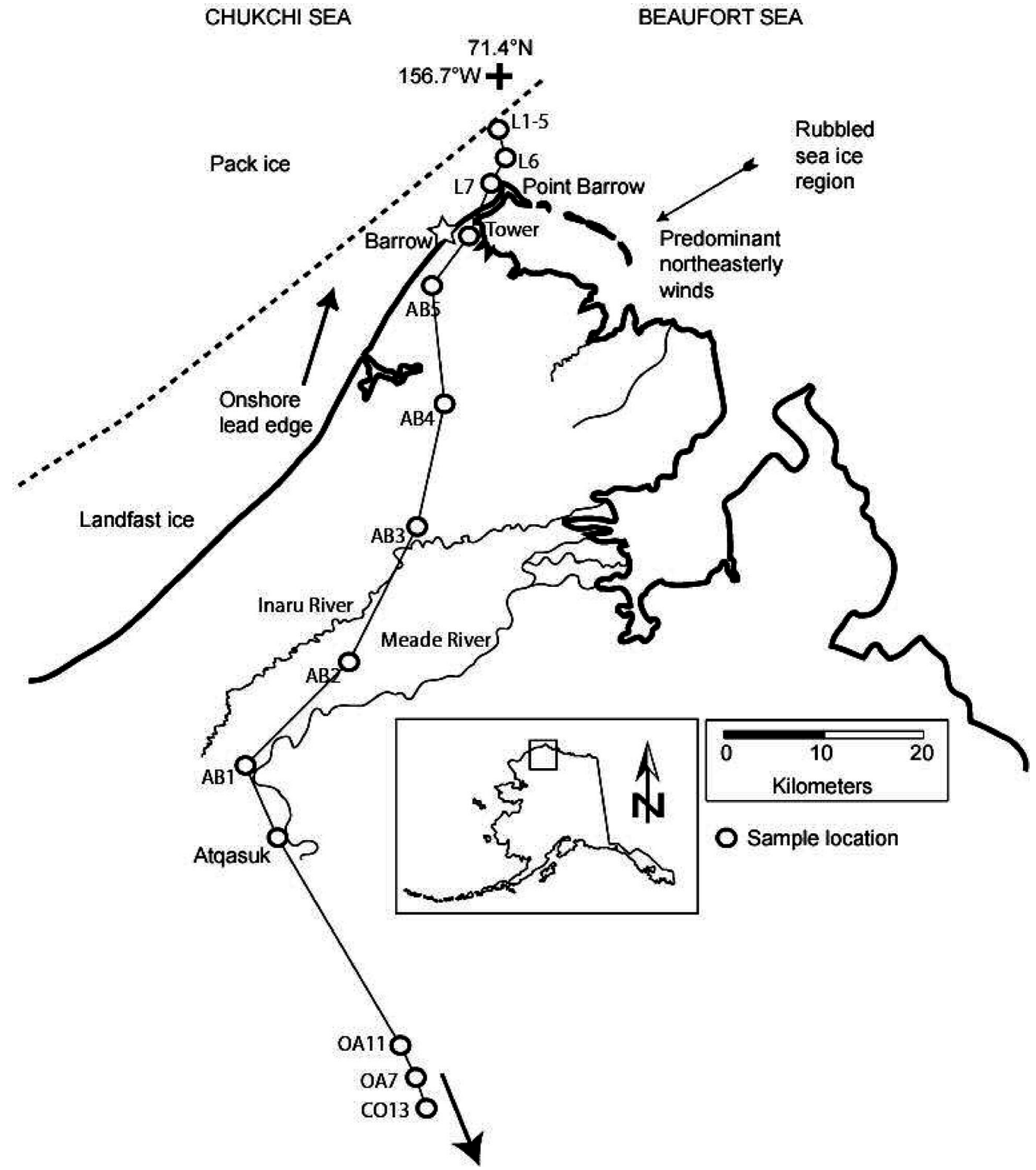

FIGURE 1. Map of the sample locations (open black circles) in this study. The atmospheric mercury monitoring equipment was located $2 \mathrm{~km}$ northwest of the Tower site (designated by the star). Transects from the lead edge inland (L1 to L7) and from Barrow to Atqasuk and beyond are shown. The three sample locations southeast of Atqasuk are not shown at their actual location to maintain a small scale for this map.

measurements. Snow and ice samples came from a $14 \mathrm{~km}$ transect from the lead to the shore at Pt. Barrow and inland several kilometers past CMDL, and from a second transect that ran $103 \mathrm{~km}$ inland from Barrow through Atqasuk (Figure 1 and Figure S4 in the Supporting Information).

Identification of Snow and Ice Crystal Types and AMDEs. We collected snow and ice crystals in the air, on the ground, and on sea ice near Barrow, Alaska (Figure 1). We sampled repeatedly to determine how mercury deposition changed with time and AMDE status. Sampling was paired with atmospheric monitoring of GEM and RGM to determine when
AMDEs were occurring. The NOAA Climate Monitoring and Diagnostics Laboratory (CMDL) is located in Barrow and provides atmospheric ozone measurements. Snow and ice samples came from a $14 \mathrm{~km}$ transect from the lead to the shore at Pt. Barrow and inland several kilometers past CMDL, and from a second transect that ran $103 \mathrm{~km}$ inland from Barrow through Atqasuk (Figure 1). Speciated mercury measurements were made using a Tekran 1130/1135/2537A system from late March to late May 2005 (17). A more detailed description of these methods is included in the Supporting Information. 
Snow and Ice Crystal Collection and Analysis. In the cold, moist environment near Barrow, a wide variety of snow and ice crystals are present in the winter and can be readily sampled. We sampled new, recent, and aged crystals that had many different depositional and post depositional histories. All snow and ice samples were collected into FEP (Teflon) bottles following ultraclean protocols (18) (and see the Supporting Information).

Sea ice lead water vapor condensate was collected by forcing condensation of atmospheric water vapor on the outside of precleaned $250 \mathrm{~mL}$ Teflon bottles filled with liquid nitrogen (boiling point $-196^{\circ} \mathrm{C}$ ). Bottles were vented to allow nitrogen gas to escape and were suspended from a $2 \mathrm{~m}$ long pole extended upwind of a boat floating in the lead. Bottles were exposed for $6 \mathrm{~min}$ and a powdery condensate coating roughly $2 \mathrm{~mm}$ thick formed on each bottle. Condensate from two bottles comprised each sample. The dual bottles from the boat yielded about $5 \mathrm{~mL}$ of melt water.

The sea ice lead water vapor condensate samples were also collected by an Aerosonde unmanned aerial vehicle (UAV) that flew over the lead at $300 \mathrm{~m}$. The UAV is made of a carbon composite material and uses a pusher-style engine at the back of the fuselage so samples collected on the leading edge of the wing are not contaminated by engine exhaust. Prior to flight, we rinsed the wing surface with deionized water to determine a background mercury concentration (1.8 ng/L). The UAV was flown through low-lying stratus clouds and the lead plume. A rime ice layer grew on the leading edge of the wing (image in the Supporting Information), which was collected into a sample bottle.

Other water vapor condensate samples included surface hoar and frost flowers that grow directly from the vapor phase $(10,13,19,20)$. The air above the ice in the Arctic and Antarctic is almost always saturated with respect to ice (21) promoting their formation as well as the formation and deposition of diamond dust, which falls under cold (below $-20^{\circ} \mathrm{C}$ ) clear skies with low turbulence conditions $(22,23)$. Frost flowers, known to grow by vapor condensation in a moist environment $(10,13,21)$, were almost always observed when the lead was open and new sea ice (nilas) was forming.

We collected vapor crystals individually with acid-cleaned tweezers or by skimming an acid cleaned $100 \mathrm{~mL}$ polystyrene scoop over the top $0.5 \mathrm{~cm}$ of the crystalline surface. Surface hoar on elevated ice blocks grew larger than on flat ice pans, particularly if the blocks faced into the wind. Frost flowers grow from water vapor but they also have a brine component of seawater wicked through pores in the sea ice (13). The most widely accepted frost flower growth sequence (24) is as follows: (1) a skim of new sea ice (nilas) forms on the ocean surface, (2) brine is fractionated upward through the ice to the surface and forms small $(<1 \mathrm{~cm}$ in diameter) bumps, (3) ice flowers nucleate on the bumps and grow over time, (4) brine is wicked up the flowers. Thus the salinity of the flowers increases as they grow and the ratio of water vapor to brine is lowest at the nucleation of the flowers and increases as they age. When we collected flowers at the lead we also collected nearby nilas and seawater (pictures in the Supporting Information). During a period of a few hours we witnessed brine nodules growing on nilas and then flowers condensing on the nodules. The frost flowers grew from roughly 1 to $5 \mathrm{~cm}$ in length in several hours and we collected samples at different stages of their growth.

The provenance of older, deposited snow was more problematic to determine. It is almost impossible to tell whether a wind-transported snow sample was derived from recently precipitated snow or older deposited snow because crystal characteristics are altered during movement through the air or along the snowpack surface. To circumvent this identification problem we collected new and recent snow samples (and diamond dust) from four glass trays placed on a $1 \mathrm{~m}$ high rack at a site called Tower $0.5 \mathrm{~km}$ south of CMDL. Saltating snow grains rarely get above $0.5 \mathrm{~m}$ during wind transport (25), so tray samples were unlikely to contain this component of blowing snow. Loose snow grains either gently moving with the wind or in small, cohesionless deposits were also collected almost daily from the snowpack at the Tower site. On most days, the top $1 \mathrm{~cm}$ of snow dunes, drifts, barchans, and sastrugi (26) (see also the image in the Supporting Information) were identified and collected using acid-cleaned $100 \mathrm{~mL}$ polystyrene scoops.

Snow was collected between the lead edge and the Tower site nine times between March 23 and April 1 to assess how far inland sea ice and leads affected mercury deposition. We also collected snow on the inland transect (Figure 1) five times in 2004. Surface layers were sampled with scoops or tweezers in the same manner as surface hoar. Deeper layers were sampled from a $2 \mathrm{~m}$ long pit excavated to the base of the snowpack (usually $\sim 30 \mathrm{~cm}$ deep) with a polyethylene shovel. Layers were characterized by their thickness, lateral continuity and grain characteristics $(27,28)$. Snow from individual layers was collected into FEP Teflon bottles. Analytical methods for mercury concentration measurements are described in the Supporting Information.

\section{Results and Discussion}

Snow and Ice Crystal Mercury Concentrations and AMDEs. Figure 2 is a plot of atmospheric mercury measurements from 2005. Open bars along the $x$-axis denote periods when GEM was below $1.6 \mathrm{ng} / \mathrm{m}^{3}$ for $8 \mathrm{~h}$. Those periods when GEM was below $0.5 \mathrm{ng} / \mathrm{m}^{3}$ and $\mathrm{RGM}$ values were elevated above background $\left(>100 \mathrm{pg} / \mathrm{m}^{3}\right)$ are the best indicator of AMDEs. The ozone mixing ratio was below 5 parts per billion by volume at CMDL during these AMDEs, supporting wellestablished correlations $(6,8-10)$. The six AMDEs identified in 2005 lasted from one day to over three weeks. Ozone measurements from CMDL were used to identify AMDEs from mid-February until our measurements at Barrow began on March 23 and suggest active AMDEs on March 13-15 and March 18-20.

Mercury concentrations in surface snow collected between the lead edge and the Arctic Ocean Coast are shown in Figure 3 separated into samples collected during AMDEs and during non AMDE periods. Samples collected when AMDEs were active (mean $=64.7 \mathrm{ng} / \mathrm{L}$; standard deviation $=41.4 \mathrm{ng} / \mathrm{L}$ ) have a statistically higher mean total mercury concentration ( $t$ test with $\alpha=0.05 ; p=0.04$ ) than the nonAMDE samples $($ mean $=40.7 \mathrm{ng} / \mathrm{L}$; standard deviation $=$ $17.5 \mathrm{ng} / \mathrm{L}$ ). Peak concentrations ranged from 35 to $198 \mathrm{ng} / \mathrm{L}$ when AMDEs were active and from 17 to $74 \mathrm{ng} / \mathrm{L}$ when they were not. These results are consistent with other studies linking AMDEs with elevated mercury concentrations in surface snow $(8,29,30)$. The mercury present in the snowpack on March 23 could be attributable to deposition during a prior AMDE. Later in the winter the non-AMDE values are harder to differentiate from the AMDE values. This suggests that some of the mercury deposited during AMDEs is retained in the snowpack after the AMDE is over.

We examined the correlation between surface snow mercury concentration and AMDEs in detail using snow collected near the trays at the Tower site. A comparison of GEM, RGM and surface snow mercury concentrations (Figure 4) suggests no strong correlation between low GEM, high RGM, or mercury in surface snow. However, there was a notable drop in surface snow mercury concentrations in late May after the AMDE season ended.

Snow and Ice Crystal types and Mercury Concentrations. Our data show a distinctive variation in mercury concentration with snow crystal type and genesis (Figure S4 and Table $\mathrm{S} 1$ in the Supporting Information). In order of decreasing mercury concentration, we found rime, diamond dust, 


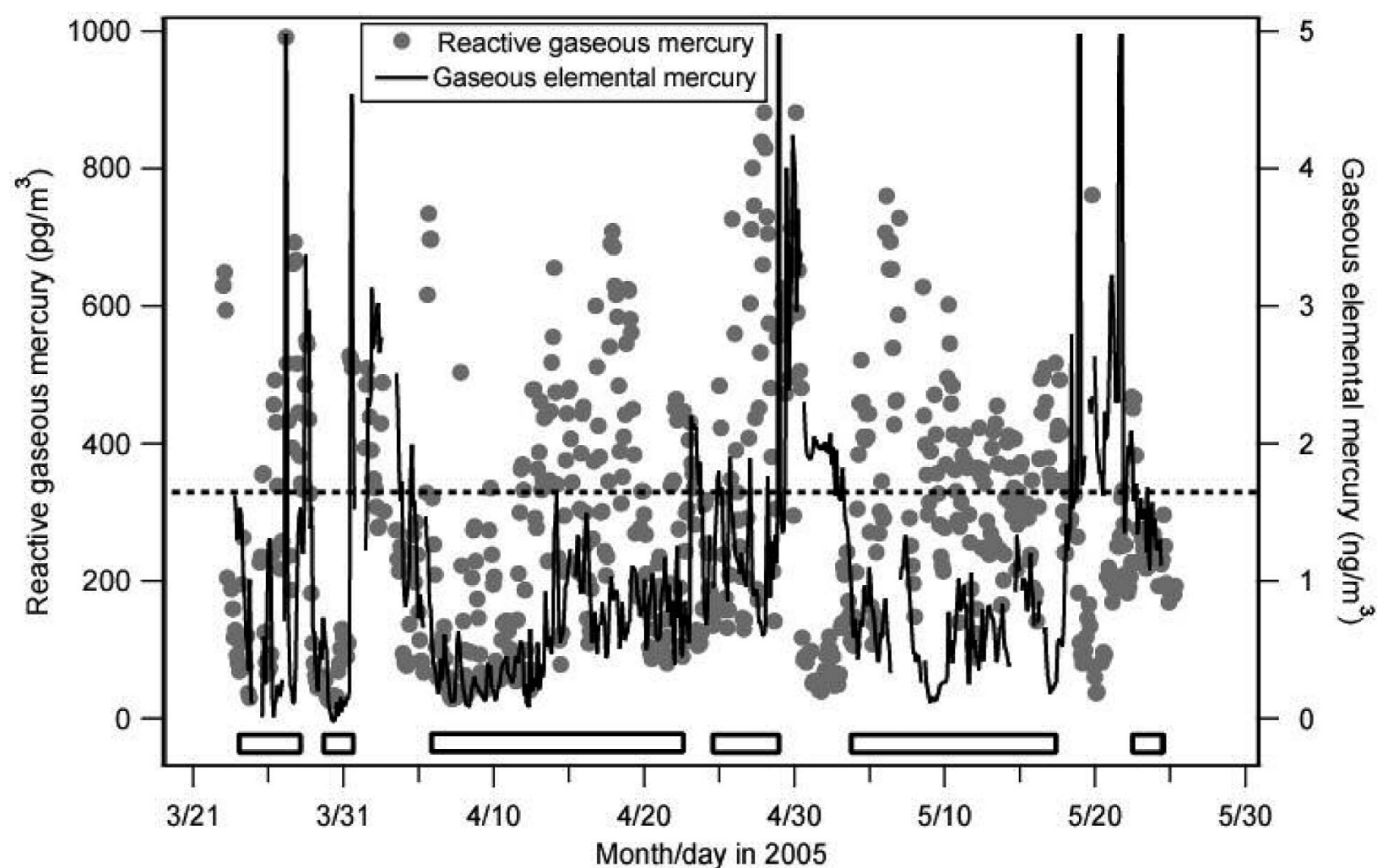

FIGURE 2. Gaseous elemental mercury and reactive gaseous mercury measured in air samples collected $2 \mathrm{~km}$ northwest of the Tower site in 2005. The dashed line denotes the $1.6 \mathrm{ng} / \mathrm{m}^{3}$ concentration while open bars denote periods when gaseous elemental mercury concentrations remained below $1.6 \mathrm{ng} / \mathrm{m}^{3}$ for eight consecutive hours or more. These periods are likely when mercury depletion events were ongoing.

perched surface hoar, and vapor-grown crystals. Older, deposited snow grains show variable but lower concentrations. There is a step change in concentration between crystals grown completely from the vapor phase collected within a few hours of their deposition (diamond dust, $2 \mathrm{~m}$ pole condensate, and surface hoar) and crystals that had uncertain but longer postdepositional histories (glass tray samples, blowing snow, and ground surface snow).

Rime Samples. The sample collected from the UAV wing, had a total mercury concentration of $15,500 \mathrm{ng} / \mathrm{L}$. The UAV was flown on March 28 when AMDEs were not active. The material from the wing and the atmospheric conditions where it formed suggest the sample represents supercooled cloudwater droplets that froze on contact (rime). Some rime could have sublimated after deposition thereby enhancing the mercury concentration but we have no direct evidence to support this. A second rime sample, from a tray placed near the lead on the same day as the UAV flight, yielded a value of $5200 \mathrm{ng} / \mathrm{L}$. A third rime sample, collected from a tray on April 27, 2006, during an AMDE yielded a value of $1580 \mathrm{ng} / \mathrm{L}$. These are the three highest mercury concentrations we observed and are among the highest reported from snow or ice in Polar Regions. These samples are all formed from liquid water in a process fundamentally different than the formation of typical dry snow.

Perched Surface Hoar Samples. Surface hoar frequently grows overnight in the study area. These large feathery crystals coat horizontal and vertical surfaces after intense radiation cooling (20). They tend to be large $(>1 \mathrm{~cm})$ when they grow on vertical or perched surfaces oriented into in the wind (i.e., a tilted ice block $1.5 \mathrm{~m}$ above the ice floe surface). Over a period of three winters we collected 10 samples of perched surface hoar ((10), this study) and they yield mercury concentrations ranging from 41 to $975 \mathrm{ng} / \mathrm{L}$. These samples may be a combination of vapor phase deposition of surface hoar and supercooled water droplet deposition of rime.
Forced Vapor Condensation Samples. The 2 m pole samples collected from the boat yielded mercury concentrations between 188 and $300 \mathrm{ng} / \mathrm{L}$. Despite the limited time they were exposed ( $6 \mathrm{~min})$, they accumulated a substantial amount of mercury. A vapor path of mist or fog could be seen migrating upward from the ocean surface and condensing on the outside of the bottle. These samples indicate that (a) there is no appreciable lag time between vapor condensation and mercury accumulation, and (b) rapid condensation of atmospheric water also gathers mercury with a mean mercury concentration of roughly $200 \mathrm{ng} / \mathrm{L}$.

Diamond Dust. Airborne diamond dust particles are 30 to $300 \mu \mathrm{m}$ long (c-axis 19,22). Because of the Kelvin effect and vapor density gradients (31), by the time we collected diamond dust from the trays, the crystals were slightly larger. Regardless, these were the smallest crystals we collected, and therefore we can assume they had the highest specific surface area (SSA (32)), the surface area of a mass of snow or ice that is available to exchange with a gas $(33,34)$. The diamond dust crystals were also the youngest crystals collected (excluding $2 \mathrm{~m}$ pole condensation). Mercury concentrations in diamond dust ranged from 92 to 1370 $\mathrm{ng} / \mathrm{L}$.

Frost Flowers. At the lead, we collected frost flowers (45 to $180 \mathrm{ng} / \mathrm{L})$, seawater $(0.5 \mathrm{ng} / \mathrm{L})$, and newly formed nilas ice $(2.6 \mathrm{ng} / \mathrm{L})$. The youngest flowers $(2 \mathrm{~h}$ old $)$ had the lowest water vapor to brine ratio and yielded the lowest mercury concentrations $(45.5 \pm 5.3 \mathrm{ng} / \mathrm{L}, n=4)$. As the flowers grew through additional vapor condensation their water vapor to brine ratio increased (24), and so did their mercury concentration. Flowers between 4 and $8 \mathrm{~h}$ old were less wet and more brittle and presumably had finished incorporating brine from the sea ice. These flowers yielded mercury concentrations ranging from 140 to $180 \mathrm{ng} / \mathrm{L}$. Frost flowers that were roughly $8 \mathrm{~h}$ old collected in a previous study (10) yielded mercury concentrations of 150 to $180 \mathrm{ng} / \mathrm{L}$. These data suggest 


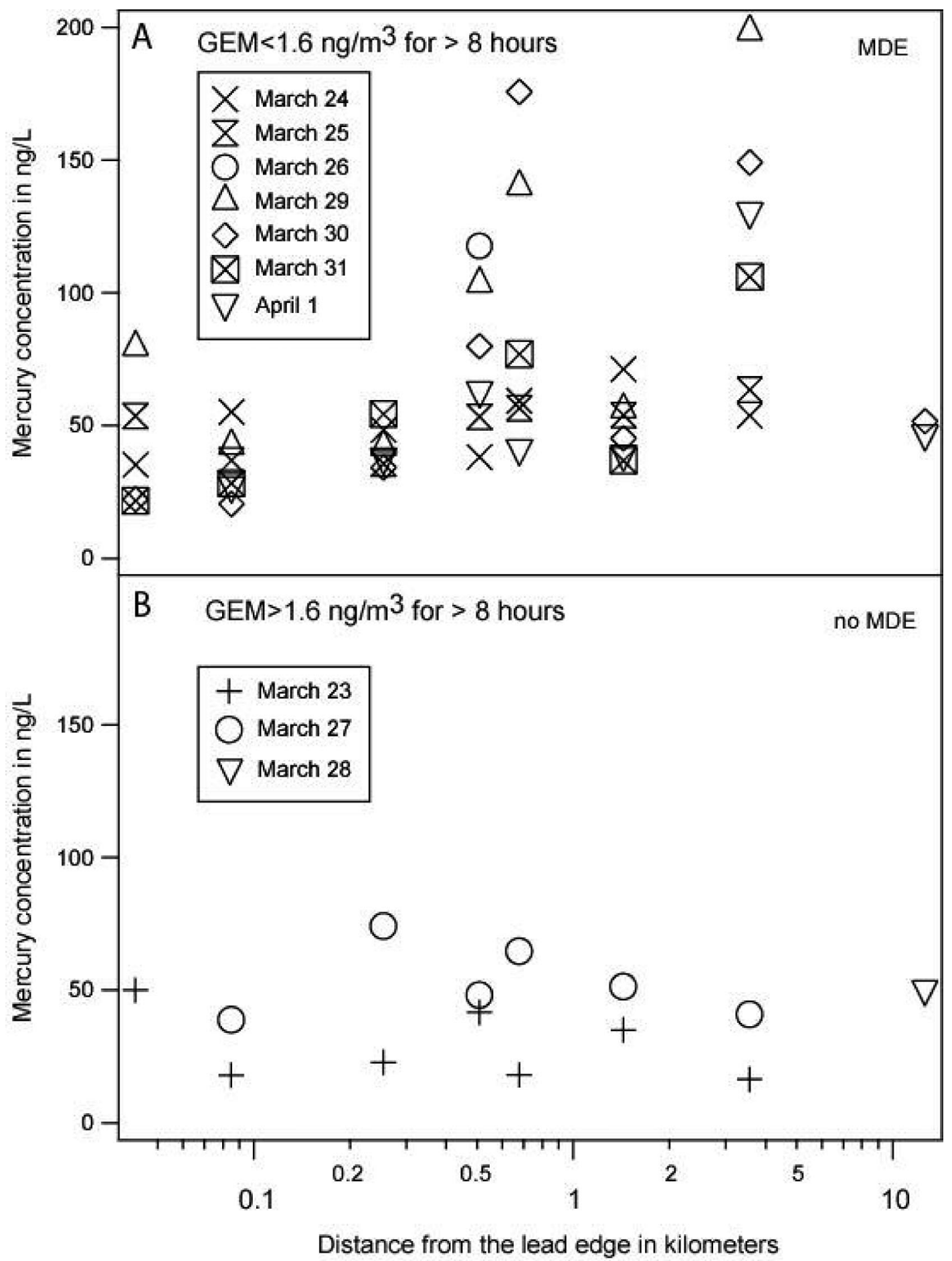

FIGURE 3. Plot of mercury concentrations in the surface $1 \mathrm{~cm}$ of snow collected along a transect from the sea ice lead edge toward the Tower site (Figure 1). Panel A shows mercury concentrations measured in surface snow collected when mercury depletion events were active while panel B shows mercury concentrations in snow collected while mercury depletion events were not active.

that fully grown frost flowers near Barrow reach a maximum mercury concentration of 150 to $180 \mathrm{ng} / \mathrm{L}$.

Normal Surface Hoar Samples. Normal (not perched) surface hoar consists of ice crystals formed through vapor phase condensation. They are fragile and can only form during low wind conditions. The lack of wind minimizes the effect of turbulent diffusive uptake and distinguishes these samples from the perched hoar samples. Surface hoar samples collected at the Tower site exhibited a very wide range of values $(321 \pm 192 \mathrm{ng} / \mathrm{L}, n=12)$.

New and Recent Precipitation Including Surface Snow. Snow collected from the surface $1 \mathrm{~cm}$ of the snowpack at the tower site (Figure 4) also yielded a wide range in mercury concentrations (3-350 ng/L) and displayed large variations over short time periods. This supports previous work at Barrow showing total mercury concentrations from $<1$ to over $90 \mathrm{ng} / \mathrm{L}$ during the late winter and spring (8). Loose surface and blowing snow from the upper $1 \mathrm{~cm}$ of the snowpack yielded lower mercury concentrations than diamond dust, surface hoar, or snow collected above the ground surface in the glass trays. From May 12 to May 30, the mercury concentration of the surface $1 \mathrm{~cm}$ of the snowpack decreased from 350 to $\sim 3 \mathrm{ng} / \mathrm{L}$ as the snow surface started to melt. A large GEM pulse from May 18 to 23 (Figure 2) may be 


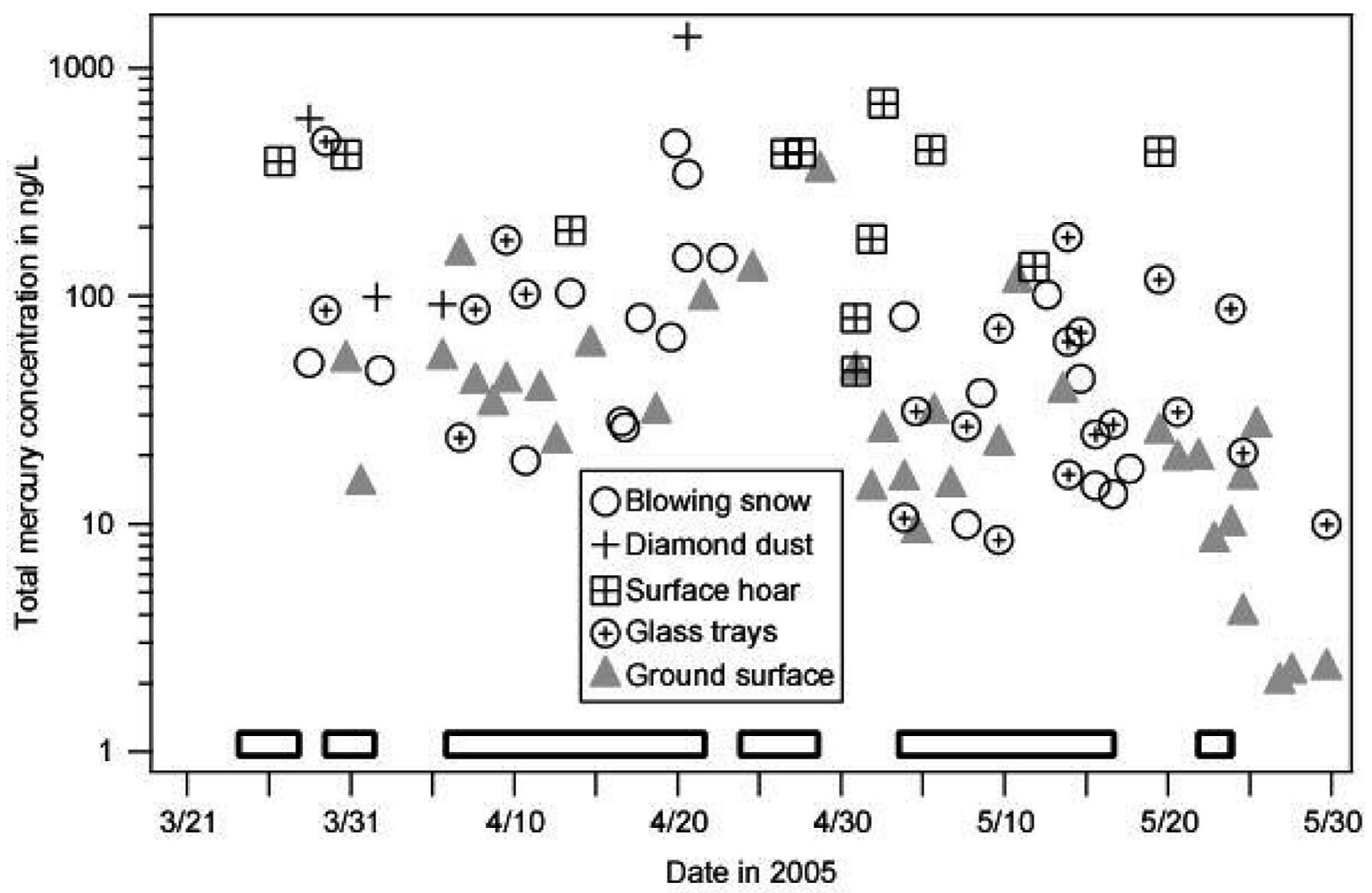

FIGURE 4. Total mercury concentrations measured in the different snow and ice crystals collected in glass trays and on the ground surface at the Tower site. The open boxes denote periods that mercury depletion events were believed to be active.

attributable to mercury reemission from the snow pack during initiation of the melt.

Deposited (Older) Snow Samples of Wind Slabs and Depth Hoar. The early spring snowpack in Barrow is usually $30 \mathrm{~cm}$ deep with a $10 \mathrm{~cm}$ base of depth hoar covered by interlayered wind slabs (highly sintered dunes of blown snow), loosely bonded snow, and typically one or two thin melt crusts (28). The snow forms an archive of the entire season's mercury deposition (18) modified by remission. Snow deposited before early February and subsequently covered by snow later in the winter was probably never exposed to an AMDE hence its initial mercury concentration would have been low. There is evidence that some mercury deposited during AMDEs is reemitted from the snowpack $(29,30,35,36)$, which also explains why older snow samples tend to have low mercury concentrations.

Depth hoar forms through snow metamorphism when there is redistribution of water vapor in the snowpack driven by strong vertical temperature gradients (27). Depth hoar crystals grow as hexagonal cups at the base of the snowpack. They are formed from early season snow that fell from October to February so they represent a snow layer that likely never contained a large fraction of mercury deposited during an AMDE. Mercury concentrations measured in depth hoar collected between Atqasuk and Barrow in $2002(n=15 ; 18)$, $2004(n=6)$, and $2005(n=11)$ yielded low values ranging from 0.5 to $7.7 \mathrm{ng} / \mathrm{L}$, with an average of $4.2 \mathrm{ng} / \mathrm{L}$.

Older snow layers are likely to have been transported by the wind. During winds greater than $5 \mathrm{~m} / \mathrm{s}$ snow grains will move along the snowpack surface, undergoing mechanical fracturing, sublimation, and sintering. With increasing distance traveled, a blowing snow grain loses its original crystal morphology and becomes equidimensional and rounded. The grain also loses water volume because of mechanical fracturing and sublimation. Adsorption or desorption of RGM onto or off of the edges of a blowing or saltating grain are possible as it travels over the snowpack surface. Thus the process of moving a snow grain will likely change its mercury composition, but in a complex manner that is difficult to predict.

Any snow sample collected without a specific time reference or formation history is simply a snapshot in time between primary mercury deposition to the snow surface during an AMDE and secondary mercury loss during reemission. The results from this study suggest that during the primary crystallization of a snow or ice crystal a simple model may explain the initial mercury composition. However, such a model must take into account the physical and chemical processes that can alter both the mass of mercury and the water volume of a sample.

During three previous field seasons in Barrow, mercury concentrations measured from wind slabs over a week old ranged from 3.7 to $203 \mathrm{ng} / \mathrm{L}(n=79$; average $=38.7$; standard deviation $=38.5$ ). Interestingly, the 35 surface snow samples collected at the Tower site in 2005 had nearly the same range: 3-250 ng/L with an average of $45.1 \mathrm{ng} / \mathrm{L}$ and a standard deviation of $63.4 \mathrm{ng} / \mathrm{L}$. Blowing snow and surface snow samples have mercury concentrations consistently between 3 and $200 \mathrm{ng} / \mathrm{L}$, probably because the snow has had an uncertain and potentially complicated history and alteration (the initial concentration and the amount of reemission are variable). The lower end of the values are controlled by the fact that snow deposited before the AMDE season likely has low ( $\sim 0-3 \mathrm{ng} / \mathrm{L})$ mercury concentrations.

Ambient air temperatures during the sampling campaign ranged from -15 to $-30{ }^{\circ} \mathrm{C}$. According to the ClausiusClapeyron relation, $1 \mathrm{~m}^{3}$ of air with $100 \%$ moisture saturation with respect to ice at $-20^{\circ} \mathrm{C}$ holds $1.2 \mathrm{~g}$ of water. RGM values in Barrow are elevated, as compared to nonpolar locations, by the oxidation of GEM during AMDEs. In Barrow during non AMDE periods RGM is typically $200 \mathrm{pg} / \mathrm{m}^{3}$ and GEM is normally $1.6 \mathrm{ng} / \mathrm{m}^{3}((8)$, this study). If water vapor quanti- 


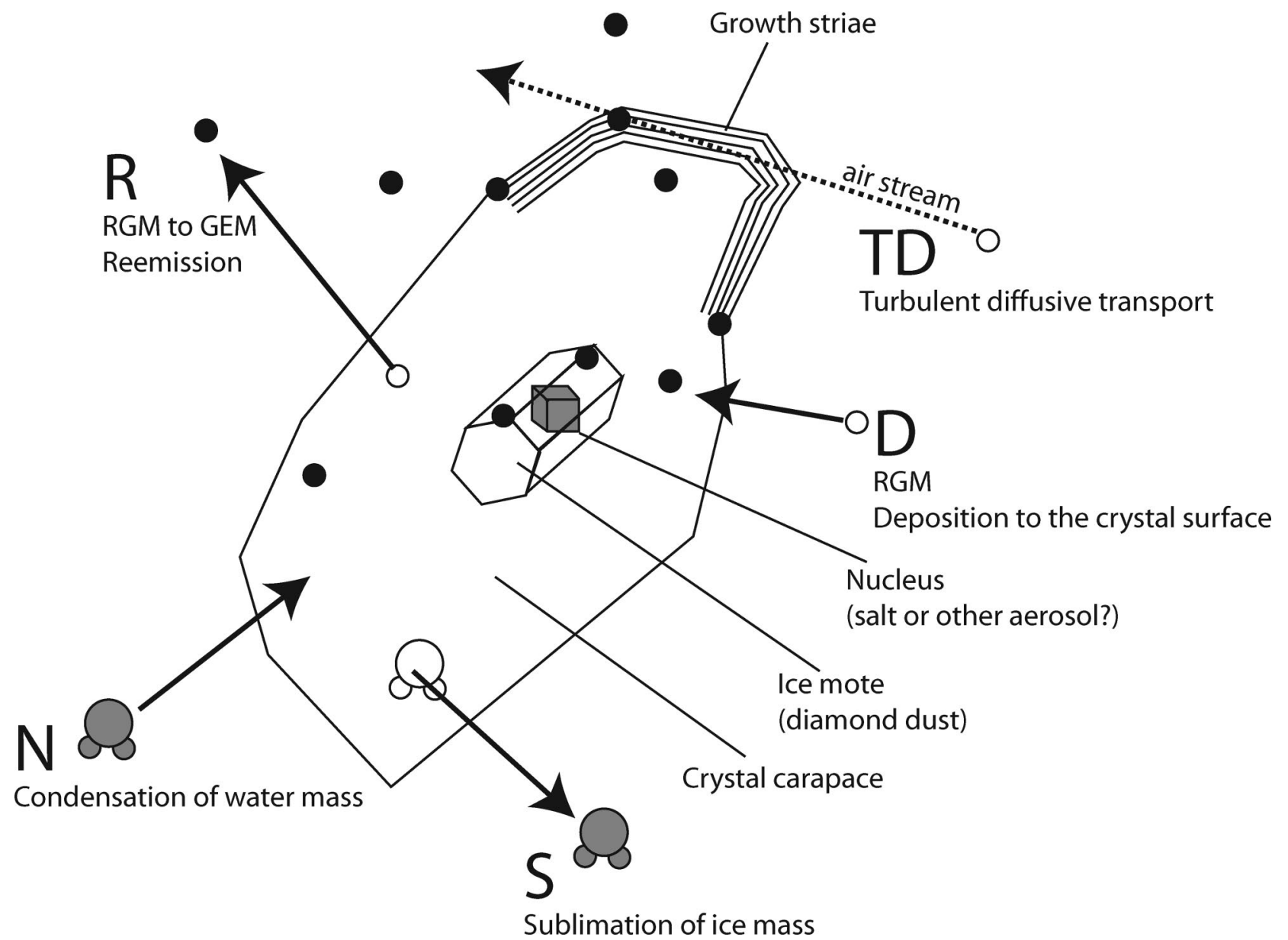

FIGURE 5. Idealized snow or ice crystal with a small nucleus and initial mote, showing the terms of the mercury mass balance equation. $\mathbf{D}=$ deposition, TD $=$ turbulent diffusive uptake, $\mathbf{R}=$ reemission, $\mathbf{N}=$ condensation, $\mathbf{S}=$ sublimation. Black circles denote RGM and/or particles with adsorbed RGM.

tatively scavenges RGM from a parcel of air with a RGM concentration of $200 \mathrm{pg} / \mathrm{m}^{3}$, the resulting condensate crystals would have a mercury concentration of $240 \mathrm{ng} / \mathrm{L}$. RGM concentrations are variable as GEM becomes oxidized and depleted during AMDEs. If all available GEM were oxidized to RGM and quantitatively scavenged by water vapor $1 \mathrm{~m}^{3}$ of air would produce ice crystals with a mercury concentration of $1900 \mathrm{ng} / \mathrm{L}$. This constrains lower and upper bounds of complete scavenging between 240 and $1900 \mathrm{ng} / \mathrm{L}$. This is the range of concentrations we observed, with diamond dust approaching the upper limit. Depositional and postdepositional processes affect the retention of mercury in/on snow or ice crystals and enhance sample heterogeneity.

Conceptual Model of Mercury Deposition to Snow and Ice. In this section we offer a conceptual model for the growth of snow and ice crystals with concurrent mercury deposition. The purpose is to provide a framework to help explain the wide variation in mercury concentrations observed in our samples. The model is not a true chemical model balancing diffusion and adsorption rates like those for hydrochloric acid and nitric acid $(37,38)$, formaldehyde (39), or hydrogen peroxide $(39,40)$ but rather an ice mass balance model to account for primary and secondary processes involved in snow precipitation and metamorphism. These ice processes affect the mercury concentration by adding or subtracting water mass, and by "locking" mercury into the ice matrix through burial from crystal growth. The mercury concentration in a snow sample is largely the result of physiochemical processes and unfortunately knowledge of the fundamental properties and behaviors of RGM is too limited to allow the chemical part of the model to be developed in detail $(41,42)$.
However, RGM is present as an oxidized, ionic form of mercury and thus would be expected to be nonvolatile. We have focused on the ice mass balance, believing it explains much of what we observed. We envision our model as a point from which fundamental properties and behaviors of RGM can be measured through laboratory and field based measurements.

The model is shown in Figure 5, a sketch of a "typical" snow or ice crystal. Regardless of how or where this crystal grew, it has three components: (1) a nucleus, sea salt aerosol, or mineral particle; (2) a small, initial crystalline mote (potentially a diamond dust particle) surrounding the nucleus that grew rapidly; and (3) an outer carapace that grew later in time, possibly in the snowpack during postdepositional metamorphism. For diamond dust, the carapace is thin and not much larger than the mote and nucleus. For depth hoar or surface hoar the carapace is thousands of times larger than the mote. With the exception of rime and ice layers (special cases in which liquid water is involved), the mote and carapace grow by vapor deposition either in a cloud (a precipitation particle) or in place (a frost flower or surface hoar crystal). For primary crystals, the carapace is derived from atmospheric moisture. For metamorphosed grains in the snowpack, a significant volume of the grain can be derived from recycled vapor from other snow grains (27). Postdepositional metamorphosed snow grains may be missing the nucleus and mote, or if they are present, they will be minute in comparison to the whole crystal.

For the snow grain shown in Figure 5, the mercury concentration, $C_{\mathrm{Hg}}$, is the ratio of a mercury mass balance to a water mass balance. When we could specifically quantify 
all the processes affecting that ratio, we could calculate the concentration by

$$
C_{\mathrm{Hg}}(\mathrm{ng} / \mathrm{L})=\frac{D_{\mathrm{Hg}}+T D_{\mathrm{Hg}}-R_{\mathrm{Hg}}}{N_{\mathrm{H}_{2} \mathrm{O}}-S_{\mathrm{H}_{2} \mathrm{O}}}
$$

where $D_{\mathrm{Hg}}$ is the amount of RGM deposited, $T D_{\mathrm{Hg}}$ is the amount of particulate mercury deposited, $R_{\mathrm{Hg}}$ is the amount of mercury reemitted, $N_{\mathrm{H}_{2} \mathrm{O}}$ is the amount of water vapor condensed onto the crystal, and $S_{\mathrm{H}_{2} \mathrm{O}}$ is the amount of water vapor lost by sublimation. The numerator is the mercury balance and is largely controlled by the chemical properties and processes. The denominator gives the water balance, with $N_{\mathrm{H}_{2} \mathrm{O}}$ and $S_{\mathrm{H}_{2} \mathrm{O}}$ describing the same processes that drive snow grain growth and metamorphism $(27,31)$. Each term in eq 1 is a function of time $(t)$ and temperature $(\theta)$, with grain size and character $(\varphi)$, light intensity and penetration $(I)$, permeability $(P)$, and relative humidity $(h)$ also affecting rates and processes.

A typical $250 \mathrm{~cm}^{3}$ snow sample collected into a sample bottle contains approximately 50000 grains. In some cases, these grains will have had a similar depositional and postdepositional history. More often, the grains will not all have the same provenance. Wind transport, or even vertical temperature variations in the snowpack, will result in grains having different origins, and certainly different postdepositional histories. Except in unusual cases, the age of the grains and crystals will not be known. Thus we must expect statistically driven scatter in observed concentrations.

The key concept behind eq 1, and what makes it useful, is that it shows that to predict chemical concentrations in snow (not just mercury but other chemical components as well), one must solve both the chemical and the water balance parts of the equation. With the exception of the idea that ice steps (43) grow across a crystal face (37), this concept is new. In the following section, we discuss the processes described by eq 1 more fully starting with the chemical processes described in the numerator followed by a discussion of the water balance processes in the denominator.

Absorption of RGM in Ice and Water. Little is known about the absorption of RGM, but the solubility of RGM is almost certainly higher in water than in ice based on work on other gas phase compounds $(44,45)$. Solubility, in addition to high surface area to volume ratios, may explain why the concentration in rime (supercooled water droplets) samples was so high (46). These samples were collected shortly after their deposition, allowing very little time for postdepositional loss of mercury. The high values may also have been the result of rapid evaporation of water or sublimation of ice after deposition. The higher solubility of RGM in water would also suggest that $D_{\mathrm{Hg}}$ would be higher as ice temperatures approach $0{ }^{\circ} \mathrm{C}$.

Adsorption of RGM by Ice. Adsorption is controlled by the crystal surface area. There are 5 orders of magnitude difference in size between a mote and a full grown surface hoar crystal. Specific surface area $(31-33,47,48)$ may be a good measure of mercury-capture efficiency by adsorption. The nucleus and the mote of a grain have high SSA values $\left(1 \times 10^{4}\right.$ to $\left.1 \times 10^{6} \mathrm{~cm}^{2} / \mathrm{g}\right)$, in contrast to larger, more fully developed ice crystals and grains, which have SSAs between 100 to $500 \mathrm{~cm}^{2} / \mathrm{g}(33,46)$. If we make a simple assumption that mercury concentration is proportional to SSA, and that samples are collected before other terms in eq 1 can alter the initial concentration, then the high concentrations found for diamond dust make sense. The SSA of diamond dust, which consists of particles not much bigger than a mote, is far higher than the $\sim 1500 \mathrm{~cm}^{2} /$ g reported as the maximum values for freshly fallen snow (32) and rimed dendritic crystals (33). Airborne cloud ice particles, the progenitors of diamond dust, have even higher SSAs than diamond dust. By measuring the mercury concentration of particles collected directly from a cloud we could verify our speculation that adsorption and SSA are important in determining the mercury concentration.

Mercury Particulate Deposition. Another poorly understood component of mercury uptake by ice crystals is particulate deposition through turbulent diffusive uptake ( $\left.T D_{\mathrm{Hg}}(49)\right)$. It is widely believed that RGM, thought to take the form $\mathrm{Hg}^{2+}$, can sorb to aerosol particles and form particulate mercury (pHg, (42)). Particulate mercury is also present in the lower troposphere and potentially codeposits with gaseous RGM. We speculate that wind blowing through fin-like crystals is an effective mechanism for $\mathrm{pHg}$ deposition. We would expect the amount of $\mathrm{pHg}$ deposited to be enhanced where air filtration is optimized, such as when air blows through intricate crystalline assemblages of surface hoar on perched blocks and vertical surfaces. Samples of these crystals exhibited elevated mercury concentrations in this study $(40-340 \mathrm{ng} / \mathrm{L})$ and even higher values in previous work $(820 \mathrm{ng} / \mathrm{L} ;(10))$.

Mercury Reemission. It is widely accepted that RGM deposited to the snowpack can be returned to the atmosphere by photoreduction to GEM $(29,30,35)$. Surface and nearsurface snow layers receive more solar radiation than more deeply buried layers, whereas older snow has had more time to re-emit mercury. Factors affecting how much mercury is lost by photoreduction include position within the ice crystal lattice where the mercury was deposited, depth of the layer within the snowpack, age, and snow temperature. Clearly, this component of eq 1 introduces significant uncertainty.

Adding/Removing Water Mass. Adding or subtracting water mass through condensation or sublimation will affect the original mercury concentration of a snow or ice grain. Most snow grains undergo multiple sublimation and condensation events, sometimes cycling on a diurnal basis. Particularly in a high-temperature gradient environment like Barrow, the flux of water molecules can be quite high $(27,31)$. This may be why older snow has a wide range of mercury concentrations. In addition to the uncertainties introduced by the terms in the numerator of eq 1, time-varying values of $N_{\mathrm{H}_{2} \mathrm{O}}$ and $S_{\mathrm{H}_{2} \mathrm{O}}$ could cause mercury dilution.

Burial by Ice Layers. The addition of ice mass by vapor condensation can occur in either kinetic or equilibrium mode $(20,31)$. Previous work has shown that in kinetic mode (ice crystallographic processes control growth) the concentration of hydrochloric or nitric acid is determined by the relative rate of burial by ice layers versus the diffusion rate of the trace gas in the ice lattice (37). It is possible that oxidized mercury, once retained in or on a snow grain, is less mobile than either hydrochloric or nitric acid and therefore less mobile $(44,45)$. Nonetheless, the idea of burial depth is still relevant when considering observed concentrations. We assume mercury buried by one or several ice layers will be retained longer than mercury that is merely adsorbed on the crystal surface. Once locked into an ice lattice, the mercury may be stable until the ice is removed by sublimation or melt. This may be the reason that we observe high mercury concentrations in vapor grown crystals collected before they can metamorphose. These vapor grown crystals include snow flakes, diamond dust, surface hoar, depth hoar, and frost flowers. The cold, moist environment near Barrow promotes this type of rapid kinetic growth: we have observed frost flowers grow $5 \mathrm{~cm}$ in $2 \mathrm{~h}$. The converse process, removal of ice layers, probably reaches a maximum rate during blowing snow events (50) that are also common near Barrow. During these events, mercury previously trapped in the ice lattice may be exposed and lost through reemission.

The last observation that we would like the conceptual model to help explain is the upper limit on concentrations (approximately $250 \mathrm{ng} / \mathrm{L}$ ) that we found in older deposited snow. We do not fully understand why this limit seems to 
exist, but we would speculate that it is related to the codeposition of mercury and water vapor and subsequent dilution by precipitation falling through a mercury-depleted air column. Other crystals like diamond dust and perched surface hoar approach the upper limit of quantitative scavenging of oxidized GEM. Subsequent processes will reduce the value.

\section{Acknowledgments}

This work was funded by the National Science FoundationOffice of Polar Programs Arctic Sciences Section: Sturm, Douglas and Perovich (0435989), Simpson (0435922), and Blum (0435893). Logistical support was provided by the Barrow Arctic Science Consortium and their assistance is greatly appreciated. Jim Barres of the University of Michigan assisted with installation and operation of atmospheric monitoring equipment. Andrew Lammers contributed to the laboratory analysis of snow for mercury. Steven Lindberg and Steven Brooks provided thoughtful suggestions during incubation and implementation of this work. Hearty discussions with Parisa Ariya, Paul Shepson, and Florent Dominé helped clarify the results and refine the conceptual model. Carl Kippe and the members of LEAD-X2005 helped construct the road to the sea ice lead. Daniel Fowler, Dennis Hipperson, Brenda Mulac, Ryan Vu, and Jim Maslanik provided aerial photos and access to rime from the Aerosonde wing. Wiley Bogren and Chris Polashenski are acknowledged for spending 3 months in Barrow sampling and overseeing atmospheric monitoring equipment. Florent Dominé, Paul Schuster and two anonymous reviewers provided detailed comments that strengthened and focused the manuscript. The authors acknowledge the memory of Gerd Hönniger, who participated in many aspects of our field work. His positive outlook and scientific expertise will be greatly missed.

\section{Supporting Information Available}

Description of the methods used for speciated mercury measurements in air and total mercury concentrations in the snow and ice samples; three figures that depict images of the different snow and ice crystal types we collected and the environments in which they form; box and whisker plot that summarizes all of the information presented in this manuscript and a table summarizing the crystal types we collected, their ages when we collected them, their specific surface areas, their mercury concentrations, and whether or not MDEs were active when the were active when they were collected (PDF). Much of this information is critical to the work presented in this manuscript but was moved to the Supporting Information because of space constraints. This information is available free of charge via the Internet at http://pubs.acs.org.

\section{Literature Cited}

(1) Cheng, M.-D.; Schroeder, W. H. Potential atmospheric transport pathways for mercury measured in the Canadian high Arctic. J. Atmos. Chem. 2000, 35, 101-107.

(2) Mason, R. P.; Fitzgerald, W. F.; Morel, F. M. M. The biogeochemical cycling of elemental mercury: anthropogenic influences. Geochim. Cosmochim. Acta 1994, 58, 3191-3198.

(3) Morel, F. M. M.; Kraepiel, A. M. L.; Amyot, M. The chemical cycle and bioaccumulation of mercury. Ann. Rev. Ecol. Syst. 1998, 29, 543-566.

(4) Wheatley, B.; Wheatley, M. Methylmercury and the health of indigenous peoples: a risk management challenge for physical and social sciences and for public health policy. Sci. Total Environ. 2000, 259, 23-30.

(5) Hausmann, M.; Platt, U. Spectroscopic measurement of bromine oxide and ozone in the high Arctic during Polar Sunrise Experiment 1992. J. Geophys. Res. 1994, 99 (D12), 25399-25413.

(6) Schroeder, W. H.; Anlauf, K. G.; Barrie, L. A.; Lu, J. Y.; Steffen, A.; Schneeberger, D. R.; Berg, T. Arctic springtime depletion of mercury. Nature 1998, 394, 331-332.
(7) Temme, C.; Einax, J.; Ebinghaus, R.; Schroeder, W. H. Measurement of atmospheric mercury species at a coastal site in the Antarctic and over the South Atlantic Ocean during polar summer. Environ. Sci. Technol. 2003, 37, 22-31.

(8) Lindberg, S. E.; Brooks, S.; Lin, C.-J.; Scott, K. J.; Landis, M. S.; Stevens, R. K.; Goodsite, M.; Richter, A. Dynamic oxidation of gaseous mercury in the Arctic troposphere at Polar sunrise. Environ. Sci. Technol. 2002, 36, 1245-1256.

(9) Banic, C. M.; Beauchamp, S. T.; Tordon, R. J.; Schroeder, W. H.; Steffen, A.; Anlauf, K. A.; Wong, H. K. T. Vertical distribution of gaseous elemental mercury in Canada. J. Geophys. Res. 2003, 108 (D9).

(10) Douglas, T. A.; Sturm, M.; Simpson, W. R.; Brooks, S.; Lindberg, S. E.; Perovich, D. K. Elevated mercury measured in snow and frost flowers near arctic sea ice leads. Geophys. Res. Lett. 2005, 32, L04502; doi:10.1029/2004GL022132.

(11) Wagner, T.; Platt, U. Observation of tropospheric BrO from GOME satellite. Nature 1998, 395, 486-490.

(12) Frie $\beta$, U.; Hollwedel, J.; König-Langlo, G.; Wagner, T.; Platt, U. Dynamics and chemistry of tropospheric bromine explosion events in the Antarctic coastal region. J. Geophys. Res. 2004, 109 (D06305);doi:10.1029/2003JD004133.

(13) Rankin, A. M.; Wolff, E. W.; Martin, S. Frost flowers: implications for tropospheric chemistry and ice core interpretation. $J$. Geophys. Res. 2002, 107(D23), 4683; doi: 10.1029/2002JD002492.

(14) Kaleschke, L.; Richter, A.; Burrows, J.; Afe, O.; Heygster, G.; Notholt, J.; Rankin, A. M.; Roscoe, H. K.; Hollwedel, J.; Wagner, T.; Jacobi, H.-W. Frost flowers on sea ice as a source of sea salt and their influence on tropospheric halogen chemistry. Geophys. Res. Lett. 2004, 31, L16114; doi:10.1029/2004GL020655.

(15) Simpson, W. R.; Alvarez-Aviles, L.; Douglas, T. A.; Sturm, M. Halogens in the coastal snow pack near Barrow, AK: Evidence for active bromine air-snow chemistry during springtime. Geophys. Res. Lett. 2005, 32 (L04811);doi:10.1029/2004GL021748.

(16) Simpson, W. R.; Carlson, D.; Hönninger, G.; Douglas, T. A.; Sturm, M.; Perovich, D.; Platt, U. First-year sea ice contact predicts bromine monoxide $(\mathrm{BrO})$ levels at Barrow, AK better than potential frost flower contact. Atmos. Chem. Phys. 2007, 7, 621627.

(17) Landis, M. S.; Stevens, R. K.; Schaedlich, F.; Prestbo, E. M. Development and characterization of an annular denuder methodology for the measurement of divalent inorganic reactive gaseous mercury in ambient air. Environ. Sci. Technol. 2002, 36, 3000-3009.

(18) Douglas, T. A. M; Sturm, M. Arctic haze, mercury and the chemical composition of snow across western AK. Atmos. Environ. 2004, 38, 805-820.

(19) Ohtake, T.; Jayaweera, K.; Sakurai, K.-I. Observation of ice crystal formation in lower arctic atmosphere. J. Atmos. Sci. 1982, 39, 2898-2904.

(20) Colbeck, S. C. On the micrometeorology of surface hoar growth on snow in mountainous areas. Bound. Layer Met. 1988, 44 (1-2), 1-12.

(21) Andreas, E. L.; Guest, P. S.; Persson, P. O. G.; Fairall, C. W.; Horts, T. W.; Moritz, R. E.; Semmer, S. R. Near-surface water vapor over polar sea ice is always near ice saturation. J. Geophys. Res 2002, 107 (C10), 15; doi: 10.1029/2000JC000411.

(22) Intrieri, J. M.; Shupe, M. D. Characteristics and radiative effects of diamond dust over the Western Arctic Ocean Region. J. Clim. 2004, 17, 2953-2960.

(23) Walden, V. P.; Warren, S. G.; Tuttle, E. Atmospheric ice crystals over the Antarctic Plateau in winter. J. Appl. Met. 2003, 42, 13911405.

(24) Perovich, D. K.; J. A. Richter-Menge Surface characteristics of lead ice. J. Geophys. Res. 1994, 99 (C8), 16,341-16,350.

(25) Pomeroy, J. W.; Gray, D. M. Saltation of snow. Water Resour. Res. 1990, 26, 1583-1594.

(26) Doumani, G. A. Surface Structures in Snow. In Proceedings of the International Conference on Low Temperature Science, Sapporo, Japan, 1966; Bunyeido: Sapporo, Japan, 1967; Vol. 1, Part 2, pp 1119-1136.

(27) Sturm, M.; Benson, C. S. Vapor transport, grain growth and depth-hoar development in the subarctic snow. J. Glaciol. 1997, $43,42-59$.

(28) Sturm, M.; Liston, G. E. The snow cover on lakes of the Arctic Coastal Plain of AK, U.S.A. J. Glaciol. 2003, 49 (166), 370-380.

(29) Ferrari, C. P.; Gauchard, P.-A.; Aspmo, K.; Dommergue, A.; Magand, O.; Bahlmann, E.; Nagorski, S.; Temme, C.; Ebinghaus, R.; Steffen, A.; Banic, C.; Berg, T.; Planchon, F.; Barbante, C.; Cescon, P.; Boutron, C. F. Snow-to-air exchanges of mercury in an Arctic seasonal snow pack in Ny-Ålesund, Svalbard. Atmos. Environ. 2005, 39, 7633-7645. 
(30) St. Louis, V. L.; Sharp, M. J.; Steffen, A.; May, A.; Barker, J.; Kirk, J. L.; Kelly, D. J. A.; Arnott, S. E.; Keatley, B.; Smol, J. P. Some sources and sinks of monomethyl and inorganic mercury on Ellesmere Island in the Canadian High Arctic. Environ. Sci. Technol. 2005, 39, 2686-2701.

(31) Colbeck, S. C. Thermodynamics of snow metamorphism due to variations in curvature. J. Glac. 1980, 26 (94), 291-301.

(32) Fassnacht, S. R.; Innes, J.; Kouwen, N.; Soulis, E. D. The specific surface area of fresh dendritic snow crystals. Hydrol. Process. 1999, 13, 2945-2962.

(33) Legagneux, L. A.; Cabanes, A.; Dominé, F. Measurement of the specific surface area of 176 snow samples using methane absorption at 77K. J. Geophys. Res. 2002, 107 (D7), 4335 doi: 10.1029/2001JD001016.

(34) Cabanes, A.; Legagneuz, L.; Dominé, F. Evolution of the specific surface area and of crystal morphology of Arctic fresh snow during the ALERT 2000 campaign. Atmos. Environ. 2002, 36 (15), 2767-2777.

(35) Lalonde, J. D.; Amyot, M.; Doyon, M.-R.; Auclair, J.-C. Photoinduced $\mathrm{Hg}$ (II) reduction in snow from the remote and temperate Experimental Lakes Area (Ontario, Canada). J. Geophys. Res 2003, 108 (D6), 4211.

(36) Kirk, J. L.; St. Louis, V. L.; Sharp, M. J. Rapid reduction and reemission of mercury deposited to snowpacks during atmospheric mercury depletion events at Churchill, Manitoba, Canada. Environ. Sci. Technol. 2006, 40, 7590-7596.

(37) Dominé, F.; Thibert, E. Mechanism of incorporation of trace gases in ice grown from the gas phase. Geophys. Res. Lett. 1996, 23 (24), 3627-3630.

(38) Dominé, F.; Rauzy, C. Influence of ice growth rate on the incorporation of gaseous HCl. Atmos. Chem. Phys. 2004, 4, 25132519.

(39) Hutterli, M. A.; McConnell, J. R.; Chen, G.; Bales, R. C.; Davis, D. D.; Lenschow, D. H. Formaldehyde and hydrogen peroxide in air, snow and interstitial air at South Pole. Atmos. Environ. 2004, 38, 5439-5450.

(40) Jacobi, H.-W.; Frey, M. M.; Hutterli, M. A.; Bales, R. C.; Schrems, O.; Cullen, N. J.; Steffen, K.; Koehler, C. Measurements of hydrogen peroxide and formaldehyde exchange between the atmosphere and surface snow at Summit, Greenland. Atmos. Environ. 2002, 36, 2619-2628.

(41) Ferrari, C. P.; Dommergue, A.; Veysseyre, A.; Planchon, F.; Boutron, C. F. Mercury speciation in the French seasonal snow cover. Sci. Total Environ. 2002, 287 (1-2), 61-69.

(42) Lindberg, S. E.; Stratton, W. J. Atmospheric mercury speciation: concentration and behavior of reactive gaseous mercury in ambient air. Environ. Sci. Technol. 1998, 32, 49-57.

(43) Frank, F. C. Snow crystals. Contemp. Phys. 1982, 23, 3-22.

(44) Thibert, E.; Dominé, F. Thermodynamics and kinetics of the solid solution of $\mathrm{HCl}$ in ice. J. Phys. Chem. B 1998, 101, 35543565.

(45) Thibert, E. Dominé Thermodynamics and kinetics of the solid solution of HNO3 in ice. J. Phys. Chem. B 1998, 102, 4432-4439.

(46) Shupe, M. D.; Uttal, T.; Matrosov, S. Y.; Frisch, A. S. Cloud water contents and hydrometeor sizes during the FIRE Arctic clouds experiment. J. Geophys. Res 2001, 106 (D14), 15,015-15,028.

(47) Dominé, F.; Cabanes, A.; Legagneux, L. Structure, microphysics, and surface area of the Arctic snowpack near Alert during the ALERT 2000 campaign. Atmos. Environ. 2002, 36, 2753-2765.

(48) Cabanes, A.; Legagneux, L.; Dominé, F. Rate of evolution of the specific surface area of surface snow layers. Environ. Sci. Technol. 2003, 37 (4), 661-666.

(49) Poissant, L.; Pilote, M.; Xu, X.; Zhang, H.; Beauvais, C. Atmospheric mercury speciation and deposition in the Bay St. Francois wetlands. J. Geophys. Res. 2004, 109 (D11301), 11.

(50) Colbeck, S. C. Sintering in a dry snow cover. J. Appl. Phys. 1998, 84 (8), 4585-4589.

ES070502D 